\title{
Toward an Evaluation of Cultural Ecosystem Services Delivered by Urban Micro-Farms
}

\author{
Giulia Giacchè $^{1, *}$, Jean-Noël Consalès ${ }^{2}{ }^{-}$, Baptiste J-P. Grard ${ }^{3}$, Anne-Cécile Daniel ${ }^{1}$ and Claire Chenu ${ }^{3}$ \\ 1 UMR SAD-APT, Université Paris-Saclay, INRAE, AgroParisTech, 75231 Paris, France; \\ anne.cecile.daniel@gmail.com \\ 2 Aix Marseille Univ, CNRS, TELEMME, 13080 Aix-en-Provence, France; jean-noel.consales@univ-amu.fr \\ 3 UMR ECOSYS, Université Paris-Saclay, INRAE, AgroParisTech, 78850 Thiverval-Grignon, France; \\ baptistegrard@gmail.com (B.J-P.G.); claire.chenu@agroparistech.fr (C.C.) \\ * Correspondence: giulia.giacche@agroparistech.fr
}

Citation: Giacchè, G.; Consalès, J.-N.; Grard, B.J-P.; Daniel, A.-C.; Chenu, C. Toward an Evaluation of Cultural Ecosystem Services Delivered by Urban Micro-Farms. Sustainability 2021, 13, 1716. https://doi.org/ $10.3390 /$ su13041716

Academic Editors: Martina Artmann, Kathrin Specht, Jan Vávra and Marius Rommel

Received: 17 October 2020

Accepted: 29 January 2021

Published: 5 February 2021

Publisher's Note: MDPI stays neutral with regard to jurisdictional claims in published maps and institutional affiliations.

Copyright: (c) 2021 by the authors. Licensee MDPI, Basel, Switzerland This article is an open access article distributed under the terms and conditions of the Creative Commons Attribution (CC BY) license (https:// creativecommons.org/licenses/by/ $4.0 /)$

\begin{abstract}
Since two decades, urban agriculture has been booming and a wide range of forms, from urban allotment gardens to rooftop farming under greenhouse, is developing. Various benefits are recognized for urban agriculture integration within the city and a specific consideration is dedicated to ecosystem services. In this article, we have focused on cultural ecosystem services provided by urban micro-farms. The state of the art reveals that urban agriculture delivers cultural ecosystem services that are well perceived and evaluated by users, but there are still few studies on this topic. Based on the analysis of specific literature on cultural ecosystems and micro-farms in parallel to a period of observation and documentary research of five urban micro-farms either on rooftop or at soil level, located in Paris and its surroundings, we proposed a specific methodology. This methodology aimed at quantitative and qualitative evaluation of the cultural ecosystem services provided by urban micro-farms and is based on a framework, which distinguishes exogenous and endogenous cultural ecosystem services.
\end{abstract}

Keywords: cultural ecosystem services; urban green space; urban agriculture; landscape

\section{Introduction}

Urban agriculture (UA) spaces are increasingly recognized for their multi-purpose nature and the ecosystem services (ES) they deliver [1-4]. Public authorities are increasingly enthusiastic about UA and the services it provides [5,6]. Mayol and Gangneron [5], in their role as reporters for the Opinion on Urban Agriculture for the French Economic, Social and Environmental Council (ESEC), emphasized the importance of compensating urban farmers for the services delivered (Recommendation 2) and of using research work to define approaches to characterize and evaluate them. Furthermore, it must be noted that knowledge gaps still remain, particularly regarding the contribution of urban agriculture types in the provision of services based on its diversity [5,7]. Among this diversity, a new form has emerged: the urban micro-farms (UMFs). They are defined by Daniel [8] as production sites for food products with a very diverse range of activities, including the sale of some or all of their production, and which are run by associations with a significant involvement of volunteers in their functioning. These characteristics differentiate them from other forms such as community gardens or urban farms [9-11]. An increasing amount of attention is being paid to the various types of professional intra-urban agriculture, with a focus on the different technical systems [12], their function and level of professional development [13,14] or their business model [15]. However, in France, the term "urban farm" does not yet have a legally defined status, unlike traditional farming operations which are defined for statistical purposes by the term "exploitation agricole" (agricultural holding) as an economic and production hub meeting three conditions: (i) they carry out a farming-based activity; (ii) they reach or exceed a certain size (area, number of 
animals, production levels, etc.); and (iii) they are managed independently. Despite this, the use of the term "urban farm" indicates an entity of a commercial and productive nature ("farm") that is located in an urban area with real and potential connections to the city and its residents ("urban"). UMFs would fall between community gardens, which are noncommercial and should help "preserve biodiversity for plants, fruits, vegetables and flowers by promoting knowledge, growth, and non-commercial exchanges between gardeners" (French Bill No. 44 (presented to the National Assembly on 17 July 2007)), and specialized urban farms with a commercial and productive nature. This is because UMFs have both an association-type organization based on volunteering with a space for sharing and interaction-like community gardens-and commercialization of food production. UMFs could be considered as agroecosystems as they are parts of the urban ecosystem devoted to food production, managed by actors deploying agricultural practices [16] that provide multiple services. During the last few years, UMFs are becoming increasingly popular in France. As shown by a non-exhaustive census conducted by the French Association for Urban Agriculture (AFAUP) (2020), there are currently 133 UMFs, of which half are in the Paris region (Île-de-France). The UMFs are not yet studied with respect to the ecosystem services delivered despite them being recognized for providing these benefits, especially cultural ones [17].

The Cultural Ecosystem Services (CESs) were defined as "the nonmaterial benefits people obtain from ecosystems through spiritual enrichment, cognitive development, reflection, recreation, and aesthetic experiences" p. 23, [18]. Although the Millennium Ecosystem Assessment is a well-recognized and widely shared reference, many different types of CESs and indicators to characterize and evaluate them can be found in the literature.

In our study, we aimed at establishing a suitable methodological framework adapted to UMFs to investigate the CESs that they provide. Hence, the present article will address the following questions: What CESs are delivered by UMFs? Who uses them? How can the perception of CESs be measured?

We mobilized an empirical-inductive approach. In fact, starting from literature review (Section 2) which allowed a synthesis of all the CESs provided, it also highlighted the lack of a specific methodological framework that we established through a pilot field research.

We selected five UMFs and proposed a specifically adapted methodological framework to deepen the understanding of CESs delivered based on actors (Section 3). The results obtained on the characteristics of the UMFs, the diversity of actors involved, and their CSEs perception led us to adjust the methodological framework (Section 4). We then discussed (Section 5) the specificities of UMFs and how the proposed methodological framework could be useful for public decision-makers and urban farmers in order to optimize the services delivered.

\section{Literature Survey: A Growing Interest in Cultural Ecosystem Services for Urban Agriculture}

Studies on CESs in urban settings stress their contribution to produce fairer cities through the creation or maintenance of spaces that provide these services [19]. Although, to make this possible, relevant and reliable indicators have to be defined based on a direct application in urban contexts for which references are missing [20]. Burkhard et al. [21] demonstrate that in central Germany, the demand for CESs (e.g., recreation and aesthetic values) is high in urban zones. Nevertheless, the natural areas (forest, grassland, beaches, sea and ocean, coastal lagoons) or green urban areas are those that have the greatest capacity to provide CESs in general. Rall et al. [22] state that the social-oriented CESs (e.g., recreational, social and cultural heritage) are concentrated more heavily in the inner-city whereas nature-oriented CESs (e.g., biodiversity, aesthetic, spiritual, connectivity to nature ... ) are located more on the edges of the cities.

A marked increase in articles on the CESs in urban settings appears from 2012 as noted by the literature review carried out by Abualhagag and Valanski [23]. However, the authors point out that the evaluation of CESs remains generally neglected in scientific literature and is restricted to commodifiable services such as leisure and ecotourism. Nevertheless, 
according to Artmann and Sartison [24], who carried out a specific study on urban and peri-urban agriculture, the most often cited ecosystem services provided by urban and peri-urban agriculture are of cultural nature. They notice 111 citations on 59 papers out of 166 . Based on their review, "tourism" opportunities play a minor role $(0.9 \%$ of total citation) as opposed to "nature experience" (17\%), "education and learning" (27\%), and "recreation and mental and physical health" (33\%), which are the most cited CESs.

Focusing attention on research studies that contribute to characterize, understand, or evaluate CESs provided by UA, two main categories emerged. A first category of studies aims to propose criteria and indicators to better characterize and evaluate CESs provided by UA $[3,25]$.

A second set of studies focus on the inhabitants and gardeners' perceptions of Ecosystem Services, including CESs provided by UA in general (6) or specific UA forms, such as agricultural parks [26,27] or community and allotment gardens [4,28-33]. The article by Sanyé-Mengual et al. [34] is particularly interesting because it studies the perception of three societal groups (project leader, stakeholders, and the general public). Moreover, they also focus on different forms of UA (e.g., community roof-top garden, CSA peri-urban farms, peri-urban farms, high-tech greenhouse, and indoor LED farming) concerning one group of actors (project leader).

Both categories of studies allow us to elaborate an inventory of CESs adapted to UA (Table 1).

Table 1. Cultural ecosystem services provided by urban agriculture.

\begin{tabular}{|c|c|c|}
\hline CES & References & Methods \\
\hline Aesthetic & {$[3,7,26-28,30,33-35]$} & $\begin{array}{l}\text { Desktop study, Questionnaires, Interviews, Mapping, } \\
\text { Observation }\end{array}$ \\
\hline Artistic inspiration & {$[7,26,35]$} & $\begin{array}{l}\text { Questionnaires, Interviews, Public Participatory Mapping, } \\
\text { Observation }\end{array}$ \\
\hline Biophilia & {$[4,28]$} & Questionnaires \\
\hline Community building & {$[7,34]$} & Questionnaires \\
\hline Contact with nature & {$[7,34]$} & Questionnaires \\
\hline Cultural heritage & {$[4,7,26,28,33,34]$} & Questionnaires, Interviews, Public Participatory Mapping \\
\hline $\begin{array}{l}\text { Ecotourism; Increasing urban } \\
\text { environment tourist attraction }\end{array}$ & {$[4,7,26,34,35]$} & Questionnaires, Interviews, Public Participatory Mapping \\
\hline Educational/Learning & {$[3,4,7,25,26,28-34,36]$} & $\begin{array}{l}\text { Desktop study, Questionnaires, Interviews, Public } \\
\text { Participatory Mapping }\end{array}$ \\
\hline Fulfilment bundle & [4] & Questionnaires \\
\hline Health/Well-being & {$[4,7,25,26,28,30,33,34,36]$} & Questionnaires, Interviews, Public Participatory Mapping \\
\hline Intrinsic value of biodiversity & [33] & Data collection \\
\hline Political fulfilment & {$[7,28,34]$} & Questionnaires \\
\hline Recreational/Leisure & {$[3,7,26-28,30,31,33-35,37]$} & $\begin{array}{l}\text { Desktop study, Questionnaires, Interviews, Public } \\
\text { Participatory Mapping, Data collection, Focus groups }\end{array}$ \\
\hline Sense of place/sense of belonging & {$[7,26,34]$} & Questionnaires, Interviews \\
\hline Social relations/social cohesion & {$[3,7,25,26,28,29,33-35,37]$} & Desktop study, Questionnaires, Interviews, Observation \\
\hline Spiritual and religious values & {$[7,26-28,34,35,37]$} & $\begin{array}{l}\text { Questionnaires, Interviews, Public Participatory Mapping, } \\
\text { Focus groups }\end{array}$ \\
\hline
\end{tabular}

The selected studies (Table 1) have mostly adopted non-monetary evaluation methods. Such methods are generally based on users' surveys, which can be criticised as being subjective. Likewise, they are able to capture and investigate the plurality of values that individuals assign to ecosystems derived from emotions and symbolism ascribed 
to urban nature [38]. The questionnaire is often preferred to in-depth interviews for having a greater representativeness and is applied online, phone-based, during face-toface surveys, or during workshops. For example, Canedoli et al. [26] experimented the participatory mapping to assess and map the CESs. They organised several workshops, involving citizens selected randomly. During workshops, they mobilized a questionnaire associated with a map, by requesting participants to localize and characterize the CESs perceived. They mapped the CESs, attributing them a score. Cavallo et al. [27] also tried to map ecosystem services at the scale of the agricultural park of Casal del Marmo in Italy. Nevertheless, they note that CESs can be hardly associated with a single land use or item, as they result from the overall use of the area and are related to both anthropic and natural elements. Other studies have also been developed coupling different methods. For example, Langemeyer et al. [28] adopted a broad database including a questionnaire, interviews, and field observation.

The literature highlights that UA delivers some services (see Table 1). In general, the most appreciated services are those related to learning, leisure, health and well-being, aesthetic, connection to nature, and social relationships.

Most of these studies reveal the importance of UA as a tool of learning and understanding nature promoting sustainable behaviour and also preserving "socio-ecological memory" [32]. Barthel et al. [32] identify five categories of learning systems based on answers of the respondent's analysis. They included the methods of learning (such as practical exercise, oral communication), the supports (that could be physical or artefacts as tools, or written material or external as reports), and the rules-in-use (as norms, regulations and property rights). Learning by doing or learning by talking with others or experts are the most cited learning system in the literature [31,32].

Gardening is often associated with "leisure or pleasure" [37] or hobby [31,35]. Speak et al. [33] reveal that allotment gardens provide important recreation services that vary, depending on people habits and rituals. These authors notice a difference between gardeners in Poznań and in Manchester. The first ones consider their plots like "summer homes", spending the summer months organizing outdoor dining, and collective activities. In Manchester, the gardeners spend much less time on the plots on which main activities were gardening and discussions with other tenants. Moreover, Manchester allotments gardens play a role for community groups and schools on education on sustainability and food.

Most studies also point out the perception of health benefits associated with UA. In particular, Porter [37] reports gardeners' perceptions that notice that gardening contributes to reducing their medication use for chronic health issues, improving emotional health and social bonding, as well as increasing access to fruits and vegetables.

Most articles show that the perception of CESs varies depending on: (i) sites characteristics (e.g., its socio-environmental characteristics); (ii) users (e.g., gender, past experiences, background); and (iii) UA forms. First, concerning spaces, Langemeyer [4] demonstrates that the "exercise and physical recreation" as well as "biophilia" are related to municipal gardens in Barcelona characterised by large areas of individual plots managed by predominantly elderly gardeners. The "political fulfilment" and "fulfilment bundle" are rather associated with community gardens created after 2009 during the economic crises.

Concerning users, women scored significantly higher than male participants' "contact with nature and spiritual experience" and "urban aesthetic and cultural/artistic inspiration" [7].

Torres et al. [29] notice also that age and occupation of respondents affect the perceptions of the garden that could be influenced by background and/or culture. These perceptions vary also according to gardens, being increasingly positive according to the age of the garden, but not with its size.

Finally, regarding the UA types, Sanyé-Mengual et al. [34] state that the activities proposed by UA farms can affect the CESs provided (e.g., the UA projects based on technological innovation developed in closed spaces that are not accessible to the public 
contributed less to CESs). Nevertheless, there still are scarce comparative studies on the perception of different forms of $\mathrm{UA}[7,34,39]$ and the results are not convergent.

However, as underlined by Borysaik and Mizgajski [25], the absence of a commonly recognized classification limits the comparison of these diverse studies.

This literature analysis confirms the lack of a common framework to study the CESs produced by urban agriculture and the near absence of surveys concerning the UMFs. The CESs provided and perceived are different according to the types of spaces and activities proposed and the existing references/framework are not complete nor well-fitted to UMFs.

Based on this literature review, we hypothesized that UMFs are agro-ecosystems that provide specific CESs that vary depending on the purpose of the UMFs project and the actors considered.

\section{Materials and Methods}

We chose five UMFs projects based in Paris and its inner suburbs (Table 2). We included a range of diverse structures in terms of size (from a hundred square meters to several hectares), location (in Paris or in the inner suburbs, on open ground in parks or on rooftops), main purpose (education, work experience, cultural or recreational), age (from the early 1990s to 2016), etc. The only common denominators were their status as an association and their multi-purpose nature.

Table 2. Main characteristics of urban micro-farms selected.

\begin{tabular}{|c|c|c|c|c|c|c|}
\hline & & UMF1 & UMF2 & UMF3 & UMF4 & UMF5 \\
\hline \multirow{7}{*}{ Site details } & Locality & Nanterre & Paris/Vincennes & Paris & istrict 20 & Aubervilliers \\
\hline & Status & \multicolumn{5}{|c|}{ Governed by the French law of 1901 on Associations } \\
\hline & Date of creation & 1992 & 2013 & 2014 & 2014 & 2016 \\
\hline & Land status & $\begin{array}{l}\text { In negotiation } \\
\text { with the City } \\
\text { Council since } \\
2016\end{array}$ & $\begin{array}{l}\text { Tenancy at will } \\
\text { with Paris } \\
\text { authorities until } \\
2020\end{array}$ & $\begin{array}{c}\text { Convention with } \\
\text { the Paris } \\
\text { schooling } \\
\text { directorate }\end{array}$ & $\begin{array}{c}\text { DASCO convention }+ \\
\text { works funded by the } \\
\text { department }\end{array}$ & $\begin{array}{l}\text { Agreement with } \\
\text { the site owner }\end{array}$ \\
\hline & Site type & $\begin{array}{c}\text { Above a } \\
\text { motorway near a } \\
\text { university } \\
\text { campus }\end{array}$ & $\begin{array}{l}\text { Historic } \\
\text { park/open } \\
\text { ground }\end{array}$ & school/rooftop & school/open ground & $\begin{array}{l}\text { Shopping centre } \\
\text { /rooftop }\end{array}$ \\
\hline & Total site area & $40,000 \mathrm{~m}^{2}$ & $1100 \mathrm{~m}^{2}$ & $145 \mathrm{~m}^{2}$ & $5819 \mathrm{~m}^{2}$ & $698 \mathrm{~m}^{2}$ \\
\hline & $\begin{array}{l}\text { Farmed area (not } \\
\text { including } \\
\text { pathways) }\end{array}$ & $1648 \mathrm{~m}^{2}$ & $683 \mathrm{~m}^{2}$ & $80 \mathrm{~m}^{2}$ & $3205 \mathrm{~m}^{2}$ & $397 \mathrm{~m}^{2}$ \\
\hline Project details & Main purpose & Cultural & Participatory & Educational & Educational & $\begin{array}{c}\text { Integration into } \\
\text { the work } \\
\text { environment }\end{array}$ \\
\hline \multirow{3}{*}{ Access } & $\begin{array}{l}\text { Distance from } \\
\text { public transport }\end{array}$ & \multicolumn{4}{|c|}{ 5-10 min from the metro or regional train lines } & $10-15 \mathrm{~min}$ \\
\hline & $\begin{array}{l}\text { Opening hours } \\
\text { for general public } \\
\text { volunteering }\end{array}$ & Sundays at 2 p.m. & $\begin{array}{l}\text { Weekends from } \\
2 \text { p.m. to } 6 \text { p.m. }\end{array}$ & $\begin{array}{l}\text { Wednesdays from } \\
9 \text { a.m. to } 12 \text { p.m. }\end{array}$ & $\begin{array}{l}\text { Wednesdays and } \\
\text { third Saturday of the } \\
\text { month from } 2 \text { p.m. to } \\
6 \text { p.m., + Thursdays } \\
\text { from } 9 \text { a.m. to } \\
\text { 12:30 p.m. during } \\
\text { harvest season }\end{array}$ & Events only \\
\hline & $\begin{array}{l}\text { Opening hour } \\
\text { details }\end{array}$ & $\begin{array}{l}\text { Opens } \\
\text { sporadically } \\
\text { during the week } \\
\text { for work or } \\
\text { events }\end{array}$ & \multicolumn{3}{|c|}{$\begin{array}{l}\text { Closed to the public outside of school term } \\
\text { times }\end{array}$} & / \\
\hline
\end{tabular}


The chosen UMFs are located in different types of sites (school, shopping centre, park, etc.), on open ground or on rooftops, and in central Paris or its inner suburbs. They are of highly varied size, ranging from $145 \mathrm{~m}^{2}$ to $4 \mathrm{ha}$, and an average of $45 \%$ of the total available area is farmed. Available space is not the only limitation, as access is restricted due to the opening hours of the hosting building or specific French national standards pertaining to the spaces (e.g., ERT [Establishments that receive workers] regulations for rooftop access to UMF3). However, the chosen UMFs are all close to public transportation and are often accessible to offer their services and activities. Although four of the five sites have an occupancy agreement, these are mostly of short duration, generally less than three years.

\section{Empirical Survey}

The pilot survey is based on an empirical mixed method approach to investigate both spaces and different types of actors and it is structured in two main steps as follows (Figure 1).

\section{CESs provided by UMFs}

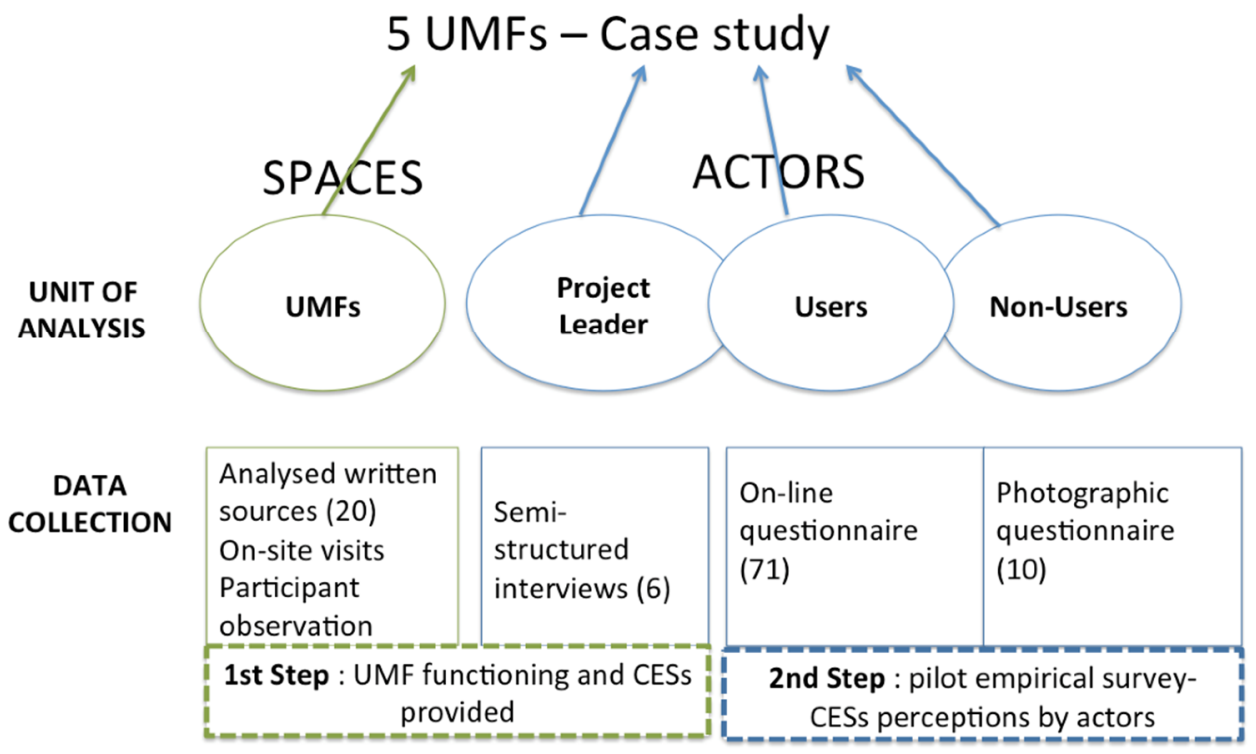

Figure 1. The structures of empirical survey. Source: Elaboration by Authors.

We first analyzed written sources (the statutes of the associations (4), their 2018 annual reports (4), and social media (Instagram, Facebook, internet sites, etc.), to better understand the functioning of UMFs. We collected quantitative and qualitative information concerning activities provided by the UMFs and the actors that we have systematized in a database.

We also performed on-site visits and participated in some ( $\left.n^{\circ} 50\right)$ events and activities (e.g., seminars, workshops, visits, party and conference) organized by UMFs from March to June 2019.

Then, during May 2019, we realized open interviews with project leaders or site managers (6) to better understand how these UMFs worked and the type of users they received. The interviews have been transcribed integrally and we have carried out thematic analysis coding the information concerning UMFs functioning, the activities, and services provides and users.

After having collected and analysed the information relating to UMFs and their activities, and the actors involved, the second stage consisted of the elaboration of two different investigation tools, adapted to two main categories of actors: the stakeholders who interact with the UMFs (users) and the residents or passersby in the neighborhood who do not participate to the UMFs activities (non-users). We tested two different questionaries. We addressed an online questionnaire to users during May-June 2019 and applied a 
face-to-face photographic questionnaire to non-users randomly solicited in metro or bus stops closest to the UMFs during June 2019. The objectives of this survey were to acquire information on attendance to UMFs, perception of CESs by users and non-users, and their socio-economic information. Concerning non-users, we aimed to understand the UMFs awareness and CESs perception. We opted for a photographic questionnaire because photo is a common tool for studying perceptions of landscape, particularly in geography [40]. A photographic questionnaire allowed us to survey a broad population (residents of the neighborhoods, passersby, tourists, etc.) and is considered a reliable survey tool. Indeed, it has been demonstrated that there is no statistically significant difference between the perception of actually visible landscapes and the perception of these same landscapes in photograph form [40]. Specific criteria were chosen to ensure that the photographs were objective: factors that might influence perception (such as light levels, season, angles, and composition) were taken into account to avoid respondents perceiving differently due to seasonal effects. Mid-season photos were chosen to show the plants at a limited stage of development, and the photos were taken at a time of day with clear visibility but not too much sun in order to avoid shadows and too stark a contrast. In addition, photos of both the inside and outside of the UMFs were necessary in order to depict the entirety of the UMFs as well as its individual details [41]. Further choices were made to ensure that the photographs used were objective. To do this, a group of six experts (landscape architect, agronomist, geographer, urbanist, sociologist, ecologist) was set up to choose the most neutral photographs through an anonymous individual votes. Two rounds of vote were necessary to reach a consensus. This protocol avoided an overestimation of individual choices and mutual participant influence.

Both questionnaires were drafted together to ensure that both groups (users and nonusers) ask similar questions, thus simplifying the comparison of the responses (Figure 2). The questionnaires are structured into three main sections.

Topic

Users Type: questionnaire

Non-users Type: photographic questionnaire

\begin{tabular}{|c|c|c|}
\hline $\begin{array}{l}\text { Section 1: Urban } \\
\text { agriculture }\end{array}$ & $\begin{array}{l}\text { Knowledge and visit habits per type and } \\
\text { location of urban agriculture }\end{array}$ & $\begin{array}{l}\text { Knowledge, perceptions and } \\
\text { representation of urban agriculture } \\
\text { landscapes }\end{array}$ \\
\hline \multirow{2}{*}{ Section 2: UMFs } & Individual practices relating to the use of UMFs & $\begin{array}{l}\text { Knowledge, perceptions, and } \\
\text { representations of the urban landscapes in } \\
\text { which the UMFs are localized }\end{array}$ \\
\hline & $\begin{array}{l}\text { Perceptions of cultural ecosystem services } \\
\text { (educational, recreational, well-being, aesthetic } \\
\text { and social) delivered by the UMF frequented }\end{array}$ & $\begin{array}{l}\text { Knowledge, perceptions, and } \\
\text { representations of the urban landscape } \\
\text { created by the UMFs (immediate environs) }\end{array}$ \\
\hline $\begin{array}{l}\text { Section 3: Socio- } \\
\text { economic profile }\end{array}$ & Socio-economic profile of the respondents & Socio-economic profile of the respondents \\
\hline
\end{tabular}

Figure 2. The structures of two questionnaires. Source: Elaboration by Authors.

Section 1 pertained to the respondents' knowledge of UA and their relationship to such sites. Users are asked about their knowledge of UA spaces and their visit habits (motivation, times, frequency, seasons, etc.) using both open and closed questions. Non-users are asked about their representations of UA and their preferences using a photographic questionnaire containing four photos, each as an illustration of different form of UA (allotments gardens, community gardens, CSA peri-urban farms, and UMFs).

Section 2 of the questionnaire was intended to understand the perceptions of services delivered by UMFs. For users, the services in question were recreational, aesthetic, 
educational, well-being, and social. The questions were designed based on indicators and metrics identified during the literature review (Table 3). For each service category, open, closed, and mixed questions are proposed in order to obtain quantitative results that can be processed statistically combined with a qualitative analysis of responses. The closed (e.g., the aesthetic indicator, evaluating the aesthetic aspect of the site on a scale from 1 to 10 or the social indicator, indicating the number of people they met at the farm and have socialized with elsewhere), open (e.g., the educational indicator, describing the skills that respondents feel they have developed by attending the farm), and mixed (e.g., the landscape aesthetic indicator, choosing which response from a list a particular urban agriculture site is most similar to) questions aimed to measure the impact and types of services and disservices delivered.

Table 3. Proposed metrics to evaluate endogenous CESs.

\begin{tabular}{cll}
\hline Services & \multicolumn{1}{c}{ Indicators } & \multicolumn{1}{c}{ Metrics } \\
\hline Recreational & $\begin{array}{l}\text { Participation in recreational } \\
\text { activities }\end{array}$ & $\begin{array}{l}\text { Number and type of activities offered } \\
\text { and number of participants } \\
\text { Preferred practices/scale from 1 to 10 }\end{array}$ \\
\hline Aesthetic & $\begin{array}{l}\text { Aesthetic value of the } \\
\text { landscape }\end{array}$ & $\begin{array}{l}\text { Scale from 1 to 10 } \\
\text { Aesthetic features characterizing UMFs }\end{array}$ \\
Educational & $\begin{array}{l}\text { Knowledge, understanding } \\
\text { and expertise acquired }\end{array}$ & $\begin{array}{l}\text { Types of skills acquired } \\
\text { Their reproducibility } \\
\text { Means of knowledge transfer }\end{array}$ \\
Well-being & Physical and mental impact & $\begin{array}{l}\text { Scale from 1 to 5 to indicate the level of } \\
\text { agreement with seven statements on } \\
\text { positive and negative feelings }\end{array}$ \\
\hline Social & Social relations & $\begin{array}{l}\text { Number of people met at the farm and } \\
\text { spent time with elsewhere }\end{array}$ \\
\hline Source: Elaborated by the authors. &
\end{tabular}

Source: Elaborated by the authors.

For non-users, the surveyed services are landscape and aesthetics. To do this, a sequence of three series of photos of UMFs are shown in order to:

- $\quad$ test respondents' knowledge of UMFs (two pictures of the outside per UMF, i.e., ten photos in total);

- $\quad$ collect representations and perceptions of the landscapes produced by UMFs (four photos of internal and external landscapes per UMF, i.e., 20 photos in total). The goal is to identify both respondents' perceptions of the quality of these landscapes (via a score from 1 to 10) and the aspects that constitute an advantage for the urban landscape. Emphasis is placed on the location of the UMF in its neighborhood (six photos).

Section 3 of the questionnaire is the same for both publics and aimed to collect socioeconomic information to identify correlations between the socio-economic profile of the respondents and their perceptions of services delivered and representations or perceptions of the landscape.

This phase of empirical research was conducted to test and improve this methodological framework to investigate CESs provided by UMFs.

\section{Results}

\subsection{Analysis of Urban Microfarms Activities and Cultural Ecosystem Services Provided}

A great variety of activities is performed within each UMF and varied according to the UMF main purposes (Table 4). Based on the documentary analysis, the results of observation, and interviews with the project leader or crop managers, we linked the activities proposed to the CESs delivered. 
Table 4. Cultural activities and services provided by urban micro-farms.

\begin{tabular}{cccc}
\hline UMF & Main Purpose & Services Delivered & CESs \\
\hline UMF1 & Cultural & $\begin{array}{c}\text { Workshops, participatory work } \\
\text { sites, parties, cultural and artistic } \\
\text { events, WWOOFing, team building, } \\
\text { experiments }\end{array}$ & $\begin{array}{c}\text { Education/Social/Recreational/Political/ } \\
\text { Landscape/Well-being/Artistic Inspiration }\end{array}$ \\
\hline UMF2 & Participatory & $\begin{array}{c}\text { Visits, workshops, participatory } \\
\text { work sites, seminars }\end{array}$ & $\begin{array}{c}\text { Social/Education/Leisure/Well-being/ } \\
\text { Intrinsic value of biodiversity }\end{array}$ \\
\hline UMF3 & Educational & Visits, school workshops, work sites & $\begin{array}{c}\text { Education/Social/Well-being/ } \\
\text { Recreational }\end{array}$ \\
\hline UMF4 & Educational & $\begin{array}{c}\text { Visits, workshops, participatory } \\
\text { work sites, seminars, team building, } \\
\text { training }\end{array}$ & $\begin{array}{c}\text { Education/Social/Leisure/Well-being/ } \\
\text { Sense of belonging }\end{array}$ \\
\hline
\end{tabular}

The UMF1 proposes the greatest diversity of activities, from electronic music parties or theater and poetry plays to specific workshop (e.g., beekeeping). In addition to the many cultural activities, UMF1 also hosts artists and artistic inspiration is one of the CESs that distinguishes this UMF among others. Moreover, an UMF1 project leader pointed out the political dimension conveyed by the project, which aims to bring "a political proposal for another agriculture, another society, as well as the creation of a public political movement".

The UMF2 relies on the participation and commitment of the association's members. They collectively produce and sell the agricultural commodities they grow. The members of the association and the employee organize some visits and workshops. The project is both professional and educational. The members practice gardening aiming to improve their skills and the production average overs years. They also stressed the intrinsic value of biodiversity that contribute to raise awareness among the many passers-by and general public to cultural values of UMF.

An association manages the UMF3 and UMF4, which are located in high school. This association mobilizes vegetable gardening activity as a pedagogy addressed to pupils but also to other people interested in training or participating. The project leader also stressed that pupils look for connectivity to nature and this physical as well as cognitive proximity help them to develop a vision of a greener city. Furthermore the crop manager of UMF4 also added that gardening develops "the feeling of belonging to" the school. The project leader also underlined that some of the pupils develop a particular interest in agriculture, which may in some cases lead them to continue with professional training.

The least accessible is UMF5, which rather develops activities geared towards professional integration for employment by relying on agricultural activity (production and sale). According to the crop manager, these activities help employees to develop awareness on food and connectivity with nature and the environment. Occasionally and episodically, public visits are organized in order to diversify the activities of the employees and provide them with skills in the field of animation.

A common element that emerges through is that food production is not the main goal and is considered as a support for other activities developed by the UMFs.

\subsection{Analysis of Users of Urban Microfarms}

As regards the people frequenting the UMFs, we identified a wide diversity of users according to their role and participation. We divided them into 13 sub-categories grouped into four categories (see Table 5). These actors have different functions within the UMFs implying a different level of involvement and engagement. 
Table 5. Types of urban micro-farms users.

\begin{tabular}{|c|c|c|c|c|c|c|}
\hline \multicolumn{2}{|c|}{ Proposed Categories and Subcategories/UMFs } & \multirow{2}{*}{$\begin{array}{l}\text { UMF1 } \\
x\end{array}$} & \multirow{2}{*}{$\begin{array}{l}\text { UMF2 } \\
x\end{array}$} & \multirow{2}{*}{$\begin{array}{l}\text { UMF3 } \\
x\end{array}$} & \multirow{2}{*}{$\begin{array}{l}\text { UMF4 } \\
\mathrm{x}\end{array}$} & \multirow{2}{*}{$\begin{array}{l}\text { UMF5 } \\
\mathrm{x}\end{array}$} \\
\hline & Project leader & & & & & \\
\hline Members & Employee(s) & $\mathrm{x}$ & $\mathrm{x}$ & $\mathrm{x}$ & $\mathrm{x}$ & $\mathrm{x}$ \\
\hline \multirow{5}{*}{ Direct users } & Civic services/trainees/student workers & $x$ & $\mathrm{x}$ & $x$ & $x$ & $x$ \\
\hline & Regular volunteers & & & $x$ & $x$ & $x$ \\
\hline & Sporadic volunteers & $x$ & $x$ & $x$ & $x$ & $x$ \\
\hline & Clients for specific training sessions & $\mathrm{x}$ & $x$ & $\mathrm{x}$ & $x$ & $\mathrm{x}$ \\
\hline & WWOOFers & $\mathrm{x}$ & & & & \\
\hline \multirow{2}{*}{ Other } & Customers at points of sale & & $x$ & $x$ & & $x$ \\
\hline & Artists & $x$ & & & & \\
\hline \multirow{4}{*}{$\begin{array}{l}\text { Sporadic } \\
\text { visitors }\end{array}$} & Schoolchildren (e.g., school trips) & & & & & $\mathrm{x}$ \\
\hline & Staff from the hosting structure & & & $\mathrm{x}$ & $x$ & \\
\hline & Company employees (e.g., team building) & $x$ & $x$ & $x$ & $x$ & $x$ \\
\hline & Public authorities & $\mathrm{x}$ & $\mathrm{x}$ & $\mathrm{x}$ & $\mathrm{x}$ & $\mathrm{x}$ \\
\hline
\end{tabular}

The common point of the five case studies is the involvement of members. In all UMFs, members and especially workers act as crop managers. They design the crop plan for the farm and the general management: choice of cropping species, irrigation, amendment, fertilization, etc. In most UMFs, direct users are mainly involved in crop maintenance, harvest, and in some cases selling the vegetables. All the tasks related to the agriculture activities are support for learning and sharing experiences. Those UMFs try to create a learning and leisure environment thanks to their agri-cultural programs addressed to various publics and based on a multiple skills of the members.

In UMF2, the running association based its productive activity on the involvement of regular volunteers, as the main goal of the project is to produce food in an urban environment through the involvement of urban citizens. UMF3 and UMF4 acknowledge many sporadic visitors as they are located in a school and involve schoolchildren (from this school or others) in their activity. However some regular volunteers attend those sites. UMF5, due to its situation on the rooftop of a building with limited access, is the only one welcoming very few people. UMF1 organizes each weekend a dedicated time when a group of volunteers help the farmer with different tasks (seedlings, soil management, weeding, etc.). They also host WWOOFers as well as artists. Furthermore, the UMF1 is characterized by the wide spectrum of people involved, from young people attracted by electronic music parties, theater and poetry enthusiasts to future beekeepers.

This classification refers only to direct users who take part in the activities offered by UMFs. Nevertheless, the impact of these activities is not limited to the boundaries of the UMFs site. Workers at the UMFs may be required to offer activities (e.g., educational workshops, events, team building) that take place outside of the site, but in line with the project (e.g., events for children in schools, team building workshops in companies, etc.), and their activities are also often shared on the Internet. Virtual and remote users should also be taken into account when considering who benefits from UMFs. An analysis of social networks revealed that three of the five UMFs studied have a Facebook page and Instagram account specifically for the projects in question. UMF3 and UMF4 do not have a website dedicated to the project but are associated with the website of the association to which they are affiliated. Therefore, it can be noted that the effects produced by these UMFs, which can be characterized by the concept of cultural ecosystem services, are not restricted to the sites themselves, nor only to those people that use them.

\subsection{The Perceptions of Cultural Ecosystem Services by Non-Users}

A lack of knowledge about neighboring UMFs emerged from the pilot in-depth (around $1 \mathrm{~h}$ ) interviews $(\mathrm{n}=10)$ with passers-by and local inhabitants. Half of the people interviewed said that they knew what UA projects were, especially allotment gardens or CSA peri-urban farms. On the contrary, they are not aware that there are UMFs in the city 
instead and the UMF term by the way is not familiar to the respondents. Moreover, the interviews revealed that the respondents are more or less consciously influenced by the presence of the UMFs. In fact, those sites are not very visible to people passing by due to their location (two projects are located on roofs and one above a motorway) or to their outline (e.g., presence of a fence). Thus, these UMFs are therefore not very visible unless the neighbors and passers-by are aware of their existence. Nevertheless, the respondents appreciated the pictures of UMFs shown during the survey. They understood the added value to the district in terms of aesthetic and CESs. The UMFs, thanks to their location in the intra-urban spaces, are integrated into the urban fabric but are not yet perceived as a part of the urban landscape. (The highly polysemic notion of "landscape" has been considered throughout this research through the lens of the definition set out by the European Landscape Convention: "'Landscape' means an area, as perceived by people, whose character is the result of the action and interaction of natural and/or human factors p. 2." [42].)

The UMFs seem to have a strong potential to be recognized as an essential green infrastructure affecting a broader public than their users, in particular the populations that live in or frequent the areas in which UMFs are created.

\subsection{The Perceptions of Cultural Ecosystem Services by Users}

Seventy-one users responded to the online questionnaire. This sample was not representative, yet it allowed us to obtain the first elements on the attendance of the UMFs as well as on the perception of the CESs.

Most respondents were women between 26 and 45 years old (Figure 3). Furthermore, 53 out of 71 were of graduate level.

\section{Age and gender of respondents}

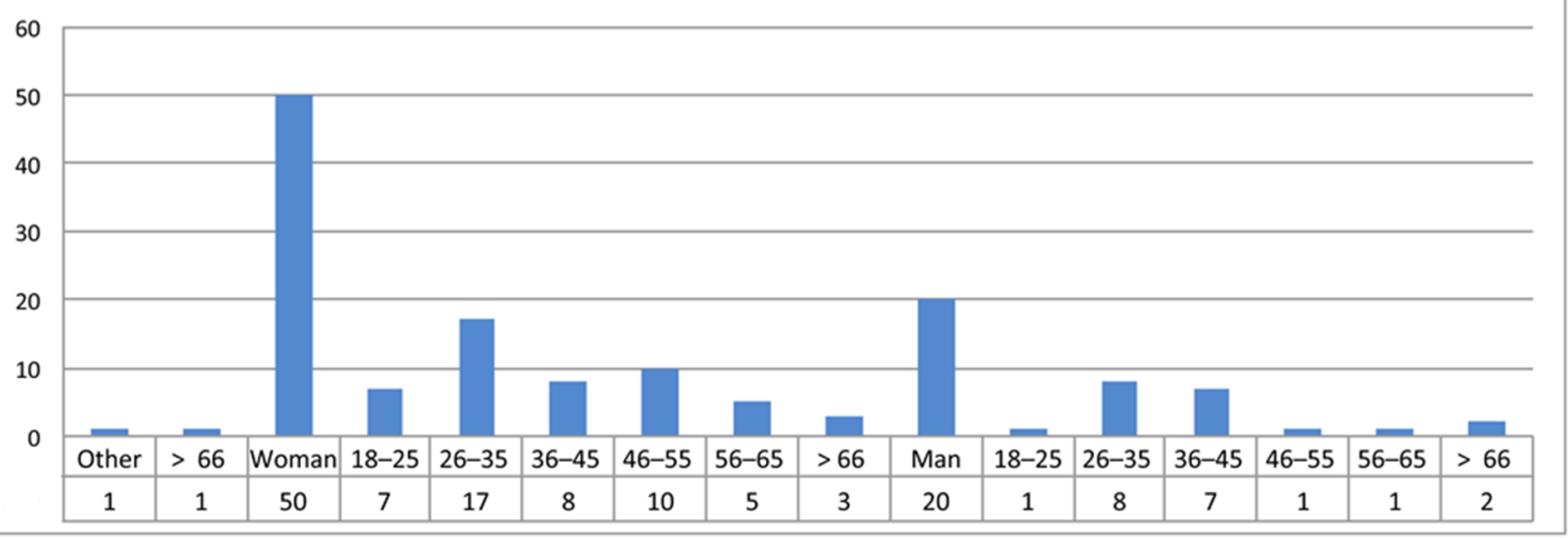

Figure 3. Age and gender of respondents.

Most people discovered the UMFs by social media (39\%), an acquaintance (35\%), passing by $(12 \%)$, or other means (e.g., study, google maps, seminar, etc.).

One seventh of respondents took less than $10 \mathrm{~min}$ on foot or by bicycle to reach the UMF and one-half of the respondents took by an average distance (from 10 to $30 \mathrm{~min}$ ) from their residence. According to these interviewees, the means of transport vary between public transport $(56 \%)$ bicycle $(33 \%)$, foot $(5 \%)$, or car $(6 \%)$. The others took from $30 \mathrm{~min}$ to an hour. This result shows that more than 50\% live near the UMFs.

The frequency is also variable: $48 \%$ of respondents frequent the UMFs once or several times a month, $38 \%$ less than 1 day per month, and $14 \%$ only once. Seasonality affects the attendance, as nearly half of the respondents do not frequent the UMFs during winter. 
The reasons expressed for UMFs frequentation vary from the atmosphere in general (76\% of respondents), connectivity to nature $(68 \%)$, learning $(61 \%)$, and contact with other people $(55 \%)$ as well as the tranquility of the place $(27 \%)$.

We asked the interviewees what did they mostly liked to do at the UMFs. Some indicated gardening activities, and others referred to more generic actions (ex; observing, taking time), which go towards an idea of reconnection with others and with nature. The answers to these questions depended on the UMFs. For example, the favorite actions of 20 out of 28 respondents that frequent the UMF1 are not "agricultural" but rather cultural or landscaping. On the contrary, respondents who frequent UMF3 or UMF4 refer in particular to gardening (ex. sawing, watering, harvest, etc.). Concerning the UMF2, both referred to farming and community life.

Regarding well-being, only three people responded that they felt positive and negative effects compared to 68 respondents who only felt positive effects. Sixty-eight respondents conferred a score equal or major to 4 (in a scale 1-5) to statements feelings like "appeasement" and "relaxation", and 56 respondents conferred the same score to "stress reduction". Regarding physical condition, 38 respondents gave a score equal or superior to 4 to the statement that "practicing activities on the farm allows them to have better endurance/better heartbeat" and only 9 attributed these values to the statement that "my back hurts after gardening ". These results show that UMFs users feel a positive impact on both mental and physical well-being.

Regarding aesthetics and landscape, 62 out of 71 people considered the landscape as a motivating criterion to frequent the UMFs. Eighty percent of the respondents conferred a score larger than 8 (in a scale 1-10) to landscape. Regarding learning and education, while 19 out of 71 respondents declared not to mobilize the skills acquired in the UMFs, 69 of them claimed to acquire some skills in plant management (e.g., sowing, transplanting and planting), handwork, as well as to work in teams.

The learning system is based on: talking to other people (11), practicing and experimenting on your own (7). Most of the respondents emphasized effectiveness of the combinations of different learning systems, in particular oral discussion with other participants and learning by doing or learning by imitation.

\subsection{Endogenous CESs and Exogenous CESs Methodological Framework}

The pilot empirical survey confirms the relevance of the distinction between users and non-users. In fact, the CESs perceived by those categories are related to their experiences that for non-users remain indirect (by viewing photos). Moreover, the CESs perceived by users (who have direct experience and attend these places) are more numerous; on the contrary, for non-users who do not know these spaces, it would therefore be difficult to imagine the services provided to UMFs and evaluate them. For this category, only aesthetic appreciation is possible. The services provided within or outside the UMFs are not the same.

These findings led us to define a new approach that distinguishes:

- $\quad$ endogenous cultural ecosystem services delivered by UMFs, i.e., all CESs produced within the UMFs themselves by or for users, defined as individuals or groups of individuals that regularly or sporadically visit the sites (urban farmers, workers, members, etc.);

- $\quad$ exogenous cultural ecosystem services delivered by UMFs, i.e., all CESs produced outside of the UMFs for non-users, defined as individuals or groups of individuals that do not visit the sites (residents, passersby, etc.). By non-users, we are referring to local residents who may benefit from the presence of a UMFs in their neighborhood.

This distinction contributes to the creation of a new methodological framework to study the CESs delivered by UMFs by way of a simultaneous and comparative evaluation of the data collected pertaining to endogenous and exogenous CESs. 


\section{Discussion}

\subsection{The Perceiving Contribution of Urban Micro-Farms to Cultural Ecosystem Services}

This research shows that UMFs are characterized by a large catchment area. Indeed, they differ from gardens or specialized farms that only involve gardeners (sometimes schools or students are mentioned as users) and farmers. A wide diversity of users, with a heterogeneous involvement as presented in Section 4.2 attend the UMFs. Compared to the bibliography, in our study the socio-professional categories were more in line with community gardens than with allotment gardens [28,31].

The UMFs also provide a wider diversity of activities than usually performed in gardens [31,32].

It is therefore necessary to take into account the UMFs specificities in order to understand which CESs are delivered and hence most relevant to study. Not all CESs listed in the bibliography are suitable to investigate the UMFs. In the selected UMFs religious inspiration or ecotourism as well as cultural heritage were not relevant. As for tourism, in fact, only one UMF hosts woofers who, however, live this experience more as a learning experience than a tourism one. Respondents did not mention religious inspiration and cultural heritage as CESs perceived. This is perhaps due to the location of the UMFs that do not stand out for historical or architectural values.

Nevertheless, our study corroborates the results found in the literature and confirms that the CESs perceived as benefits are education, leisure, well-being, and aesthetic. At the same time among the UMFs, the delivered CESs were different, depending on UMFs main purpose and the activities performed. We demonstrated that the perception of project managers concerning the CESs provided differ according to their aspiration and activities proposed (Section 4.1). For example, as indicated in Table 3, UMF1 offers a series of cultural and artistic activities and the project leader puts forward the artistic inspiration as one of the CESs delivered, while UMF4, which targets primarily pupils, identifies the sense of belonging as a CESs. We also demonstrated that the users' answers differ regarding the UMFs (Section 4.4) and they are consistent with the main purpose of the UMFs even if they are not yet representative to validate the hypothesis posed initially.

Our work highlights, more than previous studies, the importance of the landscape for frequenting UMFs. Eighty-eight per cent of respondents state that the landscape is a criterion to frequent the UMFs and $80 \%$ of them confer a high score $(8 / 10)$ to the landscape design.

Concerning the non-users, our preliminary results converge with Torres et al.'s [29] results concerning the Parisian community gardens. They state that the majority of respondents $(63 \%)$ were not familiar with the activities going on in the gardens within their neighbourhoods, although this proportion significantly differed among gardens. The oldest gardens are more familiar to respondents. Torres et al. [29] conclude, "gardens may indeed need time to be a part of residents' daily landscapes and routines" p.11.

Obviously in order to have more consistent results and to detect correlations between the CESs and the type of actors (related to age, gender, socio-economic categories), a more representative sample is required. The sample is determined as being representative by both the number of individuals surveyed compared with the reference universe and the equivalence in socio-demographic characteristics of the source population and surveyed population. For non-users, this reference framework is complied with through demographic data collected by the French National Institute of Statistics and Economic Studies (INSEE). For users, however, despite being a limited universe, its perimeter is little known. The UMFs, in fact, adopt more or less rigorous systems to keep track of visitors, especially sporadic ones, and their coordinates which, moreover, are confidential.

\subsection{Could Endogenous and Exogenous Approach Enhance the Optimization of Cultural Ecosystem Services?}

The distinction between endogenous and exogenous is fruitful because it allows understanding how to improve the provision of CESs to a wider audience. 
Quantifying and qualifying CESs has value for various actors, particularly project leaders, urban farmers, local authorities, and public authorities in general, as well as academia. The results of the survey can help both quantify (e.g., the number of participants in educational workshops and the number of skills acquired) and qualify (e.g., the types of skills acquired and knowledge transfer) the services delivered. The results can help urban farmers obtain feedback on public interest in their activities as well as information on user profiles and the efficacy in transferring the knowledge and new skills. Local authorities can better understand the impact of agricultural spaces within their districts and the evolution of urban landscape perception.

Moreover, although this enables an impact investigation both inside and outside the UMFs, it also requires time and resources to carry out this type of survey in order to have representative results. Furthermore, the resulting outcomes underline the limits in interpretation.

In terms of education and learning, our study corroborates the results found in the literature and confirms that UMFs are learning spaces for farming practices and collective and collaborative work. However, we cannot assert that gardening is the most effective practice for this. Green spaces, community gardens, and multifunctional farms in periurban areas are other types of land use that could be used as a reference if such frames of reference existed. Interpreting these results would require the indicators to be placed in the context of the spaces and respondents in question. A correct interpretation of these results requires establishing frames of reference to allow different kinds of actors to garner feedback and better understand the benefits provided by urban agriculture. Existing substitutes that can provide CESs should be taken into account [43]. Speak et al. [33] demonstrate that allotment gardens in Manchester are more recognized than allotment gardens in Poznan or parks. Unfortunately, there are still few and fragmented studies to create a reference framework.

Factors specific to each UMF must also be taken into account, including their size, intended purpose, footfall, and accessibility, which can all have an impact on both visitor numbers and users perceptions. It is therefore essential to have elements that can contextualize or correlate responses from different user profiles of UMFs. Further work needs to be developed to determine weighting factors (per UMF characteristics and footfall) to better place in context and interpret the results from user surveys. Combining quantitative and qualitative analyses will help to characterize the social impact of UMFs as well as the different representations and perceptions of how different types of urban agriculture integrate into the cityscape.

Similarly, the landscape aspect can help compare and contrast the results from the two surveys (endogenous and exogenous) and issue guidance for both public authorities and farmers. The inclusion of landscape questions in the surveys allows for a comparison of two different populations: those who use UMFs and those who do not. The perception of inhabitants (both users and non-users of these spaces) is decisive in understanding how agricultural landscapes are accepted and appreciated in a city environment. In addition, CESs, including learning and education in particular, help foster a new outlook on nature and agriculture in cities. The user survey helps reveal which aspects can characterize UMFs landscapes and which aspects users and non-users appreciate. Having more information on the perception of these landscapes and how they are structured can be an opportunity to optimize both endogenous and exogenous CESs. Feelings pertaining to the aesthetics of the site can also help guide and advise urban farmers when planning the sites and integrating them into the concrete landscape. Successful integration into urban spaces requires both recognition and an understanding of the agri-urban background. A greater knowledge of these spaces would also lead to a direct influence on the inhabitant's perception of the neighboring landscape. The recreational use that the landscape can provide is associated with how accessible and open the created landscape is [44]. The physical or visual accessibility is to be improved. It is clear that these aspects will vary significantly depending on context and the "category" of UMFs (rooftop, open ground, school grounds, etc.) [41]. 


\section{Final Remarks}

Based on the state-of-the-art, this article showed that the methodological approach to CESs provided by urban agriculture had yet to be perfected. To this end, we carried out a study on five UMFs either on rooftop or soil level, located in Paris and its surrounding areas. The awareness, knowledge, practices, and perceptions differ between those who interact with the UMFs that perfectly understand the benefits received and those who reside or pass-by close to the UMFs that are little aware of their existence.

Indeed, this study pointed out that the analysis of CESs for UMFs, in particular, and urban agriculture, in general, requires distinguishing endogenous induced effects for users (those who interact with the UMFs) and exogenous induced effects for non-users (residents or passersby in the areas with the UMFs). This distinction leads to the use of methodological approaches that differentiate, through appropriate questionnaire surveys, the practices, knowledge, perceptions, and representations between stakeholders (users) and general public (non-users). For users, UMFs provide many recreational, aesthetic, educational, well-being, and social services. For non-users, services rendered UMFs are more limited. Indeed, the UMFs are still too little known and too little recognized to have landscape and aesthetic effects still very developed. We reinforce our initial hypothesis: the UMFs are an agroecosystem providing CESs that vary according to the purpose of the UMFs but also the practices and perceptions of the various actors in the city. More importantly, this article finally discusses how the landscape can be a tangible element of comparison between the practices, perceptions, and representations of users and non-users of urban agriculture. Could landscape become the main tool for urban farmers to improve awareness towards their contribution to a greener city?

Author Contributions: Conceptualization, G.G., J.-N.C. and A.-C.D.; methodology, G.G., J.-N.C. and A.-C.D.; formal analysis, G.G., J.-N.C. and A.-C.D.; investigation, G.G., J.-N.C. and A.-C.D.; data curation, G.G., J.-N.C. and B.J.-P.G.; writing-original draft preparation, G.G., J.-N.C., A.-C.D. and B.J.-P.G.; writing-review and editing, G.G., J.-N.C., B.J.-P.G. and C.C.; supervision, B.J.-P.G. and C.C.; funding acquisition, B.J.-P.G. and C.C. All authors have read and agreed to the published version of the manuscript.

Funding: This research was funded by ADEME within the SEMOIRS research project.

Institutional Review Board Statement: Not applicable.

Informed Consent Statement: The interviewees have been informed about the aims and scope of the SEMOIRS research project. Informed consent was obtained from all persons involved in the study.

Data Availability Statement: The data are protected and stored in such a way as to guarantee anonymity.

Acknowledgments: The authors would like to thanks ADEME for funding the research project, the urban farmers that participated in the project and made it possible, as well as Antoine Manzone and Malo Lageat who participated in the data collection and investigation during their internship with the SEMOIRS research project. The authors are especially thankful to the urban farmers involved in the project and made it possible. Finally, the authors thank AgroParisTech Innovation for their support.

Conflicts of Interest: The authors declare no conflict of interest. The funders had no role in the design of the study; in the collection, analyses, or interpretation of data; in the writing of the manuscript, or in the decision to publish the results.

\section{References}

1. Clarke, L.W.; Jenerette, G.D. Biodiversity and direct ecosystem service regulation in the community gardens of Los Angeles, CA. Landsc. Ecol. 2015, 637-653. [CrossRef]

2. Lin, B.B.; Philpott, S.M.; Jha, S. The future of urban agriculture and biodiversity-ecosystem services: Challenges and next steps. Basic Appl. Ecol. 2015, 16, 189-201. [CrossRef]

3. Aerts, R.; Dewaelheyns, V.; Achten, W.M.J. Potential ecosystem services of urban agriculture: A review. Peer J. Prepr. 2016, 4, e2286v1. 
4. Langemeyer, J. The Generation of Ecosystem Services in Urban Gardens from a Socio-Ecological Systems Perspective, Technical Report. 2014. Available online: https://www.urbanallotments.eu/fileadmin/uag/media/STSM/Langemeyerr_STSM_Report_ short_final.pdf (accessed on 21 September 2020).

5. Mayol, P.; Gangneron, E. Opinion of CESE, Agriculture Urbaine: Un Outil Déterminant Pour Des Villes Durable; CESE: Paris, France, 2019; 90p, ISBN 978-2-11-152226-8.

6. ANRU. Les Carnets de L'innovation. Agriculture Urbaine Dans Les Quartiers en Renouvellement Urbain; Boîte à Outil du Montage d'un Projet; ANRU: Paris, France, 2019; 101p.

7. Sanyé-Mengual, E.; Specht, K.; Krikser, T.; Vanni, C.; Pennisi, G.; Orsini, F.; Giaquinto, G.P. Social acceptance and perceived ecosystem services of urban agriculture in Southern Europe: The case of Bologna, Italy. PLoS ONE 2018, 13, e0200993. [CrossRef]

8. Daniel, A.C. Fonctionnement et Durabilité des Micro-Fermes Urbaines. Une Observation Participative sur le cas des Fermes Franciliennes; Study Report; Chaire Eco-conception: Paris, France, 2017.

9. Aubry, C. L'agriculture urbaine, contributrice des stratégies alimentaires des mégalopoles? In Proceedings of the 24th Environmental Science Days-The Ecological Transition of Mega-Cities, Créteil, France, 12-14 February 2013.

10. Opitz, I.; Berges, R.; Piorr, A.; Krikser, T. Contributing to food security in urban areas: Differences between urban agriculture and peri-urban agriculture in the Global North. Agric. Hum. Values 2016, 33, 341-358. [CrossRef]

11. Simon-Rojo, M.; Recanes, X.; Callau, S.; Duzi, B.; Eiter, S.; Hernandez-Jimenez, V.; Laviscio, R.; Lohrberg, F.; Pickard, D.; Scazzosi, L.; et al. From urban food gardening to urban farming. In Urban Agriculture Europe Book; Lohrberg, F., Licka, L., Scazzosi, L., Timple, A., Eds.; Jovis Publishing: Berlin, Germany, 2015; pp. 22-28.

12. Morel-Chevillet, G. Agriculteurs Urbains; Éditions la France Agricole: Paris, France, 2017; 269p.

13. De Biasi, L.; Lagneau, A.; Aubry, C.; Daniel, A.C.; Collé, M. L'agriculture urbaine au Coeur des projets de ville, IAU. Note Rapide Environ. 2018. Available online: https://www.institutparisregion.fr/fileadmin/NewEtudes/Etude_1478/NR_779_web.pdf (accessed on 19 September 2020).

14. Clerino, P.; Lelièvre, A. Formalizing objectives and criteria for urban agriculture sustainability with a participatory approach. Sustainability 2020, 12, 7503. [CrossRef]

15. Kasmi, D.; Duchemin, E.; Martin, J. Les Entreprises Agricoles Urbaines au Quebec: Impact Economique et Potentiel de Développement; Laboratoire sur l'agriculture urbaine/Carrefour de Recherche; d'expertise et de Transfert en Agriculture Urbaine, 2020; 37p. Available online: http:/ / cretau.ca/wp-content/uploads/2020/06/Etude-Les-entreprises-agricoles-urbaines-au-Qu\%C3\%A9 bec-impact-\%C3\%A9conomique-et-potentiel-de-d\%C3\%A9veloppement_F.pdf (accessed on 21 September 2020).

16. Conway, C.R. Agroecosystem analysis. Agric. Adm. 1985, 20, 31-55. [CrossRef]

17. Daniel, A.C. Les micro-fermes urbaines, de nouvelles fabriques agri-urbaines. VertigO Rev. Electron. Sci. Environ. 2018. [CrossRef]

18. Sarukhan, J.; Whyte, A. (Eds.) Ecosystem and Human Well-Being: A Framework for Assessment; Island Press: Washington, DC, USA; Covelo, CA, USA; London, UK, 2003; 266p. Available online: https:/ / pdf.wri.org/ecosystems_human_wellbeing.pdf (accessed on 21 September 2020).

19. Andersson, E.; Tengo, M.; McPhearson, T.; Kremer, P. Cultural ecosystem services as a gateway fro improving urban sustainability. Ecosyst. Serv. 2015, 12, 165-168. [CrossRef]

20. La Rosa, D.; Spyra, M.; Inostroza, L. Indicators of Cultural Ecosystem Service for urban planning: A review. Ecol. Indic. 2016, 61, 74-89. [CrossRef]

21. Burkhard, B.; Kroll, F.; Nedkov, S.; Muller, F. Mapping ecosystem service supply demand and budgets. Ecol. Indic. 2012, 21, 17-29. [CrossRef]

22. Rall, E.; Bieling, C.; Zytynska, S.; Haase, D. Exploring city-wide patterns of cultural ecosystem service perceptions and use. Ecol. Indic. 2017, 77, 80-95. [CrossRef]

23. Abualhagag, A.; Valanski, I. Mapping indicators of cultural ecosystem services: Review and relevance to urban context. J. Landsc. Ecol. 2020, 13, 4-24. [CrossRef]

24. Artmann, M.; Sartison, K. The Role of Urban Agriculture as a Nature-Based Solution: A Review for Developing a Systemic Assessment Framework. Sustainability 2018, 10, 1937. [CrossRef]

25. Borysiak, J.; Mizgajski, A. Cultural Services provided by urban allotment garden ecosystems. Ekon. Sr. $2016,4,59$.

26. Canedoli, C.; Bullock, C.; Collier, M.J.; Joyce, D.; Padoa-Schioppa, E. Public Participatory Mapping of Cultural Ecosystem Services: Citizen Perception and Park Management in the Parco Nord of Milan (Italy). Sustainability 2017, 9, 891. [CrossRef]

27. Cavallo, A.; Pellegrino, D.; Di Donato, B.; Marino, D. Values, roles and actors as drivers to build a local food strategy: The case of Agricultural Park of Casal del marmo. In Proceedings of the 7th International Aesop Sustainable Food Planning Conference Proceedings "Localizing Urban Food Strategies. Framing Cities and Performing Rurality", Torino, Italy, 7-9 October 2015; Cinà, G., Dansero, E., Eds.; Politecnico di Torino: Torino, Italy, 2015; pp. 355-364, ISBN 978-88-8202-060-6.

28. Langemeyer, J.; Camps-Calvet, M.; Calvet-Mir, L.; Barthel, E.; Gomez-Baggethun, E. Stewardship of urban ecosystem services: Understanding the value(s) of urban gardens in Barcelona. Landsc. Urban Plan. 2018. [CrossRef]

29. Torres, A.C.; Prévot, A.C.; Nadot, S. Small but powerful: The importance of French community gardens for residents. Landsc. Urban Plan. 2018, 180, 5-14. [CrossRef]

30. Polombo, N.; Yengué, J. Services socio-économiques rendus par les espaces verts urbains. In Proceedings of the Comparaison de 2 Parcs Urbaines en Région Centre, Oral Commination at 5ème National Health and Environment Congress, Rennes, France, 25-27 November 2014. 
31. Breuste, J.H.; Artmann, M. Allotment Gardens Contribute to Urban Ecosystem Service: Case Study Salzburg, Austria. J. Urban Plan. Dev. 2015, 141, 141. [CrossRef]

32. Barthel, S.; Folke, C.; Colding, J. Social-ecological memory in urban gardens-Retaining the capacity for management of ecosystem services. Glob. Environ. Chang. 2010, 20, 255-265. [CrossRef]

33. Speak, A.F.; Mizgajski, A.; Borysiak, J. Allotment gardens and parks: Provision of ecosystem services with an emphasis on biodiversity. Urban For. Urban Green. 2015, 14, 772-781. [CrossRef]

34. Sanyé-Mengual, E.; Specht, K.; Vavra, J.; Artmann, M.; Orsini, F.; Giaquinto, G. Ecosystem Services of Urban Agriculture: Perception of Project Learders, Stakeholders and the General Public. Sustainability 2020, 12, 10446. [CrossRef]

35. Calvet-Mir, L.; Gomez-Baggethum, E.; Reyes-Garcia, V. Beyond food production: Ecosystem services provided by home gardens. A case study in Vall Fosca, Catalan Pyrenees, Northeastern Spain. Ecol. Econ. 2012, 74, 153-160. [CrossRef]

36. Bally, F. Quels services écosystémiques culturels sont produits par des citoyens et quelles valeurs y associent-ils? Environ. Urbain 2017, 11. [CrossRef]

37. Porter, C.M. What gardens grow: Outcomes from home and community gardens supported by community-based food justice organizations. J. Agric. Food Syst. Community Dev. 2018, 8 (Suppl. 1), 187-205. [CrossRef]

38. Stalhmmar, S.; Pedersen, E. Recreational cultural ecosystem services: How do people describe the value. Ecosyst. Serv. 2017, 26, 1-7. [CrossRef]

39. Specht, K.; Weith, T.; Swodoba, K.; Siebert, R. Socially acceptable urban agriculture businesses. Agron. Sustain. Dev. 2016, 36, 17. [CrossRef]

40. Le Lay, Y.F.; Piégay, H.; Cossin, M. Les enquêtes de perception paysagère à l'aide de photographies: Choix méthodologiques et exemples en milieu fluvial. In Proceedings of the 7th Meeting of ThéoQuant, Besançon, France, 26 January 2005.

41. Lageat, M. Une Caractérisation des Services Ecosystémiques Culturels “Exogènes" des Micro-Fermes Urbaines en Mobilisant L'entrée du Paysage. Master's Thesis, Engineering of Urban Green Spaces, AgroParisTech, Paris, France, 2019.

42. Council of Europe. European Landscape Convention; Council of Europe: Strasbourg, France, 2000.

43. Keeler, L.B.; Hamel, P.; McPherson, T.; Hamann, M.K.; Donahue, M.L.; Meza Prado, K.A.; Arkema, K.K.; Bratman, G.N.; Brauman, K.A.; Finlay, J.C.; et al. Social-ecological and technological factors moderate the value of urban nature. Nat. Sustain. 2019, 2, 29-38. [CrossRef]

44. Therond, O.; Tichit, M.; Tibi, A.; Accatino, F.; Biju-Duval, L.; Bockstaller, C.; Bohan, D.; Bonaudo, T.; Boval, M.; Cahuzac, E.; et al. Volet "Ecosystèmes Agricoles" de L'evaluation Française des Ecosystèmes et des Services Ecosystémiques; Research report; INRAE: Paris, France, 2017; 970p. Available online: https:/ / www.inrae.fr/sites/default/files/pdf/efese-services-ecosystemiques-rendus-parles-ecosystemes-agricoles-rapport-complet-4.pdf (accessed on 21 September 2020). 